\title{
Jamie Peck, 2005: Struggling with the Creative Class
}

\author{
Su Lin \\ Department of Linguistics and Translation, City University of Hong Kong, Hong Kong, China \\ Email: sulin3-c@my.cityu.edu.hk
}

How to cite this paper: Lin, S. (2021). Jamie Peck, 2005: Struggling with the Creative Class. Open Journal of Social Sciences, 9, 365-371.

https://doi.org/10.4236/jss.2021.93023

Received: February 16, 2021

Accepted: March 23, 2021

Published: March 26, 2021

Copyright (c) 2021 by author(s) and Scientific Research Publishing Inc. This work is licensed under the Creative Commons Attribution International License (CC BY 4.0).

http://creativecommons.org/licenses/by/4.0/

\begin{abstract}
Since the 1990s, the popularity of cultural and creative industries has been set off worldwide, and the creative economy has become a new and important growth of the regional economy. Around the theme of cultural and creative industries, its derivative research fields, such as public policies, governance, cultural, industrial parks, art industrial, etc., are also highly sought after by people. However, at this stage, it seems that the public only sees the positive aspects of cultural and creative industries but seldom focuses on their negative aspects. This paper mainly reviews Peck's critical analysis of Florida bestsellers The Rise of the Creative Class. And how it is Transforming Work, Leisure, Community and Everyday Life, and makes an in-depth analysis around the creative class and in connection with the advanced viewpoints of index scholars in the field of cultural and creative industries.
\end{abstract}

\section{Keywords}

Creative Class, Creative City, Cultural and Creative Industry, Creative Economy

\section{Introduction}

\subsection{The Origins of the Term Creative}

It is a critical review essay published in International Journal of Urban and Regional Research. For the Creative Class, then, primarily we need to review the origins of the term Creative. In 1944, Theodor Adorno and Max Horkheimer built the interpretation of the culture industry, which is the production of standardized cultural commodities and destroys ingenuity (Kong, 2014: p. 594). In the late 1960s, people became optimistic about the cultural industry because capital injection contributed to the innovation of the culture industry (Hesmondhalgh \& Baker, 2011: p. 25). Meanwhile, the term which turned from the culture 
industry into culture industries represents the admit of cultural diversity and unique and lead the concept of creative industries (Kong, 2014: p. 594). In 1997, The British government released the term "creative industry" which promotes the development of the economy (Kong, 2014: p. 595). The term of creative is "agile" in political and conveys a feeling of positive (Pratt, 2008: p. 113). It is worth mentioning that John Hawkins pointed out in his book The Creative Economy. How People Make Money from Ideas published in June Howkins (2001) that the world's creative economy creates 22 billion US dollars in a single day and is increasing at a rate of $5 \%$. Therefore, we cannot ignore the creative class, which is the driver of the cultural and creative economy.

\subsection{Peck's Overall Insights on Creative Class}

This is an intense, suasive, heated debated and individualistic exploration of the significance of creative class and creative city policy against Richard Florida and a critical review of Florida's best seller book, The Rise of the Creative Class. And how it is Transforming Work, Leisure, Community, and Everyday Life. Peck translates and interprets the central thesis of the work; the urban capitals shift to attract "class of creatives" (p. 740) and regard them as the "primary drivers of economic development" (p. 740). Besides, a large number of city leaders across the world keen on through practicing Florida's theory on the development of creative cities, their cities will achieve competitiveness in economic globalization. One apparent fact is that many cities are obsessed with the pursuit of the creative index, "the three T's" (p. 740) and creative city ranking which is called "the Creative 100" (p. 743). More sharply, Peck considers the "unstopped social revolution" (p. 741) of "creative age" (p. 741) is exaggerated "sales pitch" (p. 741) and "marketing" (p. 741) of Florida (2004).

Of course, Peck did not deny the creative class. He maintains that:

As the source, apparently, of all good economic things, the Creative Class must be nurtured and nourished, its talents must be harnessed and channeled. (p. 743)

The cult of urban creativity is therefore revealed in its true colors, as a form of soft law/lore for a hypercompetitive age. (p. 768)

Many city leaders take the initiative to release public policies and increase capital investment to make their cities more creative and thus improve their competitiveness. Whether these efforts will be rewarded or not, and whether the urban economy will be significantly developed, the results are not necessarily. As Peck mentions, "even as their material payoffs remain extraordinarily elusive" (p. 768).

This article is organized into five Parts, accompany with quotes, notes, and a list of bibliography. It is impressed just how fruitful is covered in a thesis of only just 31 pages. Around the world, the creative class is a hot topic. Civic leaders are fighting to attract and retain creative people and establish creative cities. In this paper, geography professor Jamie Peck does not obey the ordinary thoughts but 
analyzes urban-studies theorist Richard Florida's thesis and discusses urban planners, civic leaders, creative people, and in previous urban trends and development.

\section{Deep Consideration of Peck's Struggling with the Creative Class}

From "Creative class, rising" in Part One, Peck summarizes and interprets arguments of Richard Florida in the book, The Rise of the Creative Class. Peck also points out the mode and current situation of Florida's theory popularization. Florida is so favored by many "urban planners", especially "leftish policy-makers" from all over the world (p. 740). To summarize in Peck’s own words:

(Florida) has proved to be a hugely seductive one for civic leaders around the world, competition amongst whom has subsequently worked to inflate Florida's speaking fees well into the five-figure range. (p. 740)

From Singapore to London, Dublin to Auckland, Memphis to Amsterdam; indeed, all the way to Providence, RI and Green Bay, WI, cities have paid handsomely to hear about the new credo of creativity. (p. 740)

Peck insights many people publicize this vision without criticism. So, Peck reviews a cluster of books and articles and lists abundant viewpoints which against the Creative Class of Richard Florida: 1) Dreher takes notes of the idea of Florida is "contradiction" in terms (p. 741); 2) The right undertakes mainly criticisms on "anti-immigrant and homophobic" (p. 741); 3) While the left has some scattered but powerful disagreements such as "innocent, aloof, or tactically perching" (p. $741)$; 4) Peter Marcuse, Florida's former teacher, comments the book that "it reads like a series of well-crafted after-dinner speeches at various chamber of commerce dinners" (p. 741). Peck himself pointed out sharply the political views and positions in The Rise of the Creative Class are contradictory:

This ambiguity is echoed in the politically ambivalent arguments contained in The Rise of the Creative Class, which mixes cosmopolitan elitism and pop universalism, hedonism and responsibility, cultural radicalism and economic conservatism, casual and causal inference, and social libertarianism and business realism. (p. 741)

Besides, Peck thinks Creativity is "banal" indeed (p. 741), but Florida knows packaging turgidly and publicity of the theory well. Some "new-economy predecessors" such as "Fast Company" is defined as "our allies" on Florida's https://www.creativeclass.org web site (p. 742).

The argument moves in Part Two ("Creative juices") focuses on the interpretation of Florida's creative core and essence. Creativity has always been the key to economic growth; that is to say, creativity is not a new thing. However, the Creative Class must be educated, guided, and taken care. From this perspective, the book, The Geography of Genius from Eric Weiner in 2016 can illustrate that creative is not an innovation, but nature human beings hold. Eric Weiner re- 
searched "genius clusters" shaped in particular areas at different historical periods. He did a series of global field investigations in seven cities present from ancient to modern. Even though he does not draw specific conclusions on what kind of environments formed creative clusters, he summarizes the common characteristics of genius in different periods of development in different cities. Weiner has an insight into which places attract creative genius, "Places such as ancient Athens, or Silicon Valley today, are creative because they attract smart, ambitious people" (Weiner, 2016: p. 29). This argument seems similar to Florida's opinions that for the pursuit of economic generation, cities should turn to be creative for an attraction of the Creative Class (p. 740). We can see from Figure 1 that, there are human-made principles to guide planners to make the cities creative. However, if every city in the world turns to be as the Memphis Manifesto says, there is still creative or replicative?

In Part Three (Biscotti and circuses), and crucially, urban plays a critical role in "account of the Creative Class" (p. 746). The key proposition of Florida is that "three T's-“technology, talent, and tolerance" (p. 746) - is essential to make urban creative and bring creative class. Florida invented a way to rank cities around the world in terms of creativity which make the civic leader keen on the "Creative Index" ranking list (p. 747). Moreover, it is just a marketing tool which makes the urban leaders and residents feel well (Pratt, 2008: pp. 108-109). Creativity index has become a new index to evaluate the work of city leaders in some

The Creative 100 are dedicated to helping communities realize the full potential of creative ideas by encouraging these principles:

1) Cultivate and reward creativity. Everyone is part of the value chain of creativity. Creativity can happen at anytime, anywhere, and it's happening in your community right now. Pay attention.

2) Invest in the creative ecosystem. The creative ecosystem can include arts and culture, nightlife the music scene, restaurants, artists and designers, innovators, entrepreneurs, affordable spaces, lively neighborhoods, spirituality, education, density, public spaces and third places.

3) Embrace diversity. It gives birth to creativity, innovation and positive economic impact. People of different backgrounds and experiences contribute a diversity of ideas, expressions, talents and perspectives that enrich communities. This is how ideas flourish and build vital communities.

4) Nurture the creatives. Support the connectors. Collaborate to compete in a new way and get everyone in the game.

5) Value risk-taking. Convert a "no" climate into a "yes" climate. Invest in opportunity-making, not just problem-solving. Tap into the creative talent, technology and energy for your community. Challenge conventional wisdom.

6) Be authentic. Identify the value you add and focus on those assets where you can be unique. Dare to be different, not simply the look-alike of another community. Resist monoculture and homogeneity. Every community can be the right community.

7) Invest in and build on quality of place. While inherited features such as climate, natura resources and population are important, other critical features such as arts and culture, open and green spaces, vibrant downtowns, and centers of learning can be built and strengthened. This will make communities more competitive than ever because it will create more opportunities than ever for ideas to have an impact.

8) Remove barriers to creativity, such as mediocrity, intolerance, disconnectedness, sprawl, poverty, bad schools, exclusivity, and social and environmental degradation.

9) Take responsibility for change in your community. Improvise. Make things happen Development is a "do it yourself" enterprise.

10) Ensure that every person, especially children, has the right to creativity. The highest quality lifelong education is critical to developing and retaining creative individuals as a resource for communities.

Figure 1. The Memphis manifesto (Source: Peck, 2005: p. 743). 
terms. We can image that, the city leaders will firstly implement current strategies, secondly invite Florida to speak, thirdly appoint experts to develop the creative city policy. Peck picks four examples to demonstrate the relationship between the people and the cities in the dimension of creativity. "Cool City" (p. 751) in Michigan comes first. More than 120 communities work out a plan just through the imitation of the state program quickly. He also lists two "grass-roots organizations" (p. 753) related to creative cities. One called Creative Tampa Bay which holds "the first creative cities summit" (p. 751) supported by some local institutions, the other one named "Cincinnati Tomorrow" develops strategies for city image and adapt to the creative class. What this is a far cry from three examples before, here then, as a representative of the creative class, Florida moved from Pittsburgh to Washington, from a city that lacked the creativity to a more creative city.

In the first three Parts, as its most basic, Peck discussed and reviewed the Creative Class superficially, while in Part Four, he explored the problems hidden behind deeply. Peck reveals that most human beings are not "Creative individuals," just as:

Florida (2004) insists that his "super creative core" of scientists, artists and techies "is really the driving force in economic growth," just as it has become evident that "what drives a city..." (p. 757)

In other words, it is worrying that he believes that most workers are lack of creativity and cannot be the driving force of urban development, thus ignoring them and giving priority to the creative class. As discussed earlier in the article, creativity is necessary for human beings, but creativity is uncertain. It is necessary to doubt the core role of creative strategies in urban development. In short, the theory of creative stratum is not a strategy to train talents in general, but a policy to serve the elite layer. Just as Peck points out:

The Rise of the Creative Class has also attracted criticism for its relative neglect of issues of intraurban inequality and working poverty. (p. 756)

Arts journalist Scott Timberg (2016) proposes in Culture Crash: The Killing of the Creative Class, the creative class can make society better, but when only the rich access art, cultural diversity disappears. Therefore, if only a small group of people can enter the creative class, then the artistic creation itself will be destroyed.

In the final Part, Peck discusses the Creative Class in the view of urban policymaking. In his opinion, the policy maker or the civic leader who held the power play a dominant role in the development of creative cities. Florida's creative strategies indeed "commodify the arts and cultural resources" rather than "civilizing urban economic development by bringing in culture" (p. 763). From this aspect, there seems no different from the concept of the culture industry in 1944. It is not progress, but a regression. Besides, to cater to the elite and become the goal of the creative city policy. Florida regards "individuality, meritocracy, 
diversity, and openness" as "the core values" to the "creative ethos" (p. 764).

\section{Summary}

At present, the growth rate of human science, technology, knowledge, and economy is faster than ever before which forcing city managers to find out the direction of city development, so that city-led globalization enters a new dynamic stage. In this regard, the exploration of the new economic era, many city leaders around the world have taken the initiative to introduce public policies and increase capital investment to make cities more creative, thus improving their competitiveness. City leaders are trying to attract and retain creative people and build creative cities. Taking Jamie Peck, a scholar of geography, as an example, this paper analyzes the papers of Richard Florida, an urban research theorist, and discusses urban planners, urban leaders, creative people, and the urban development trends.

Some scholars express themselves very directly, such as Andy C. Pratt. With the development of economic globalization and knowledge, "manufacturing relocation is simple: move into knowledge business" (Pratt, 2008: p. 110). Some scholars express themselves in obscurity. The report published in 2015, Future Cities: Driving Growth Through the Creative Economy, through the overview of how creativity influences their economy and life in five metropolises (Austin, Berlin, Mexico City, Mumbai, and Seoul) may find ways to face the new challenge of the new coming era.

Meanwhile, the creative class has the character of "individuality, meritocracy, diversity, and openness" (p. 764). Florida's logic is, first of all, that creativity is the driving force of urban development; secondly, strong creativity only exists in the creative class, so we must attract the creative class into the city. It deducts to the conclusion that a city expects to become a creative city, so long as it implements the same strategies and policies, it will become creative. However, the process of forming a creative city is the same: how creativity still exists? Peck insights that Florida's "creativity strategies were in a sense preconstituted for this fast policy market" (p. 767). Cities with high creative index are booming, but whether the root cause of the growth is the creative class is unknown. To show achievements and follow Florida's footsteps, it seems a wise choice and shortcut for city leaders to implement creative strategies.

\section{Conflicts of Interest}

The author declares no conflicts of interest regarding the publication of this paper.

\section{References}

Florida, R. L. (2004). The Rise of the Creative Class: And How It's Transforming Work, Leisure, Community and Everyday Life. New York: BasicBooks.

Future Cities: Driving Growth through the Creative Economy. (n.d.). http://creativecities.eiu.com/ 
Hesmondhalgh, D., \& Baker, S. (2011). Creative Labour: Media Work in Three Cultural Industries. London: Routledge.

Howkins, J. (2001). The Creative Economy: How People Make Money from Ideas. London: Allen Lane.

Kong, L. (2014). From Cultural Industries to Creative Industries and Back? Towards Clarifying Theory and Rethinking Policy. Inter-Asia Cultural Studies, 15, 593-607. https://doi.org/10.1080/14649373.2014.977555

Peck, J. (2005). Struggling with the Creative Class. International Journal of Urban and Regional Research, 29, 740-770. https://doi.org/10.1111/j.1468-2427.2005.00620.x

Pratt, A. C. (2008). Creative Cities: The Cultural Industries and the Creative Class. Geografiska Annaler: Series B, Human Geography, 90, 107-117. https://doi.org/10.1111/j.1468-0467.2008.00281.x

Timberg, S. (2016). Culture Crash: The Killing of the Creative Class. New Haven: Yale University Press.

Weiner, E. (2016). The Geography of Genius: A Search for the World's Most Creative Places from Ancient Athens to Silicon Valley. New York: Simon \& Schuster. 